\title{
Investigation of the processing characteristics of soybean sprouts after germination of HaePum during a long storage period with different temperature and humidity
}

\author{
Yun Ju Lee ${ }^{1} \cdot$ Won Byong Yoon ${ }^{1,2}$ (D)

\section{장기 저장 중 저장 온도와 습도에 따른 해품 콩의 콩나물 가공적성 연구}

이윤주1 - 윤원병1,2

Received: 25 November 2019 / Accepted: 26 December 2019 / Published Online: 31 March 2020

(C) The Korean Society for Applied Biological Chemistry 2020

\begin{abstract}
This study investigated the processing characteristics of soybean (HaePum) sprouts based on temperature $(5,15$ and room temperature), period $(0,6$ and $12 \mathrm{mon})$ and relative humidity $(20,40,60$, and $80 \%)$ during storage. The initial germination rate of soybean sprouts was $76.02 \pm 6.32 \%$, which significantly reduced to $57.18 \pm 8.51 \%$, and $0 \%$ as the storage temperature of soybean increased for a period of $12 \mathrm{mon}$. The germination rate of soybean sprouts with $30{ }^{\circ} \mathrm{C}$ and $80 \% \mathrm{RH}$ decreased after 4 mon of storage to $4.94 \%$. The yellowness of cotyledon of soybean sprouts was not significantly changed during the 12 mon period of storage at $5{ }^{\circ} \mathrm{C}$, whereas, soybean sprouts stored at $15^{\circ} \mathrm{C}$ and room temperature demonstrated decreased yellowness. However, the stress of cotyledon decreased with an increase in both storage temperature and time, and the hardness of hypocotyl decreased with an increase of storage time. The stress of cotyledon affected by high temperature $\left(30{ }^{\circ} \mathrm{C}\right)$ and humidity (80\%) during 4 mon was reduced to $44.39 \pm 9.38 \mathrm{~g} / \mathrm{mm}^{2}$.
\end{abstract}

\section{Won Byong Yoon $(\bowtie)$}

E-mail: wbyoon@kangwon.ac.kr

${ }^{1}$ Department of Food Science and Biotechnology, Kangwon National University, Kangwon 24341, Republic of Korea

${ }^{2}$ Elderly-Friendly Food Research Center, Agriculture and Life Science Research Institute, Kangwon National University, Kangwon 24341, Republic of Korea

This is an Open Access article distributed under the terms of the Creative Commons Attribution Non-Commercial License (http://creativecommons. org/licenses/by-nc/3.0/) which permits unrestricted non-commercial use, distribution, and reproduction in any medium, provided the original work is properly cited.
The asparagine content of soybean sprouts showed a similar result with the germination rate due to the amount of hypocotyl. Therefore, lower temperatures and shorter storage times are suitable for soybean sprout processing. The first order kinetic model and Arrhenius equation (activation energy $=29.56 \mathrm{~kJ} / \mathrm{mol}$ ) were able to predict the yield of sprout at various storage temperatures and periods.

Keywords Free amino acids $\cdot$ Germination rate $\cdot$ Soybean sprouts - Storage period $\cdot$ Storage temperature

\section{서 론}

콩(Glycine $\max$ L. Merrill)은 우리나라를 비롯한 동양에서 중 요한 영양공급원으로 이용되어 왔으며[1], 단백질 함량이 높은 작물로서 여러 형태로 조리 또는 가공하여 섭취해 오고 있다 [2]. 콩 단백질은 일반적으로 콩의 건조 중량 대비 약 $35-45 \%$ 함유되어 있다[3]. 대표적인 콩 가공제품으로는 청국장, 된장, 두 부, 콩나물 등이 있으며, 그 중 콩나물은 소립콩을 원료로 하여 재배하는 제품이다[4]. 콩나물은 배축을 식용으로 이용하기 때 문에 발아력이 높고 배축 신장이 빨라야 한다. 또한 콩나물 콩 의 발아 및 신장은 재배환경(저장 온도, 저장 기간)에 의하여 발아 시 콩나물의 생육과 품질, 수율에 영향을 미친다. 농림부(2009)에 의하면 국내 콩 시장은 연간 1,676 천 톤이 생 산 및 수입되어[5] 저장을 하며 가공에 이용한다. 그 중 나물용 콩은 저장 기간이 증가할수록 발아율이 감소하여 5년 후에는 발아가 전혀 되지 않을 뿐만 아니라 콩나물의 수율, 품질 등이 
하락하기 때문에 나물 콩의 저장 기간이 2 년을 초과하지 않은 종자를 원료 콩으로 이용하도록 권장되고 있다. 식용 콩은 주 로 저장 온도와 상대습도에 따라서 퇴화 되기 때문에 저온 저 장이 권장되지만 재배농가는 대부분 온도 조절이 되지 않는 창 고에 콩을 보관하기 때문에 계절적으로 온도 편차가 커 가공 후 제품 품질에 영향을 미칠 수 있다[6].

콩나물의 품질 중 발아율은 생산 수율에 가장 큰 영향을 미 치는 요인이며 나물 콩은 단명종자로서 수확 후 6 9개월 이상 실온에서 저장하면 발아율이 감소한다[7]. 그리고 콩나물은 저 장 기간이 증가할수록 저작 시 특유의 아삭거리는 식감이 감소 하는 특성이 있다[8]. 콩나물의 품질에 대한 연구로는 나물용 콩의 파종 시기가 단백질, 이소플라본 등의 기능성 성분과 발 아율에 미치는 영향 $[1,9]$, 재배기간에 따른 콩나물의 총 아미 노산 함량 변화[10] 등이 수행된 바 있다. 그러나 최적 가공을 위한 나물 콩의 저장 기준은 미비한 실정으로, 가공적성 평가 를 위해서는 물리적 품질 특성에 대한 연구가 필요하다. 이와 같은 연구를 진행하기가 어려운 이유는 3 개월 이상의 장기간 동안 일정한 저장 조건을 유지하며 보존한 콩을 이용하여 가공 특성을 평가하는 것이 어렵기 때문이다. 본 연구는 온도와 습 도 저장 조건을 유지하며 각각 12 개월과 4 개월까지의 저장 조 건에 따른 콩나물의 특성을 고찰하였다.

\section{재료 및 방법}

\section{실험재료}

실험에 사용한 콩나물용 콩인 '해품'은 농촌진흥청 국립식량과 학원으로부터 제공받았으며 저장온도 및 저장기간에 따른 실험 용 콩은 2017년 11 월에 생산된 것으로서 $5,15^{\circ} \mathrm{C}$, 실온으로 조절된 저장고(DryStore ${ }^{\circledR} 8.4 \mathrm{~L}$, Centor Thai, Thailand)에서 0, 6,12 개월 저장된 해품을 사용하였다. 추가적으로 저장온도와 저장습도에 따른 가공적성을 연구하기 위한 실험용 콩은 2018 년 11 월에 생산된 콩으로서 저장온도가 $5,30{ }^{\circ} \mathrm{C}$, 실온에서 상 대습도가 $20,40,60,80 \%$ 로 조절된 저장고 안에서 2 개월과 4 개월 저장된 해품을 사용하였다.

\section{콩나물의 재배방법}

원료 콩 $30 \mathrm{~g}$ 을 $18^{\circ} \mathrm{C}$ 에서 6시간 침지 후 콩나물 재배기(SC$9000 \mathrm{~A}$, Shinchang Inc., Osan, Korea)에 넣었다. 관수 조건은 20 분 당 1 분씩 관수하면서 $18^{\circ} \mathrm{C}$ 의 인큐베이터(LMI-1002R, Daihan Labtech Co., Ltd., Namyangju, Korea)에서 6일간 재 배하였다.

\section{발아세}

Germination rate $(\%)=\frac{N_{g}}{N_{i}} \times 100$

$N_{g}$ : 발아 5 일간 $5 \mathrm{~cm}$ 이상 성장한 발아립 수

$N_{i}$ : 초기 콩의 수를 나타냄

\section{재배 수율}

Yield $(\%)=\frac{G_{y}}{G_{i}} \times 100$

$\mathrm{G}_{\mathrm{y}}$ : 콩나물의 수확 직후 무게 $(\mathrm{g})$

$\mathrm{G}_{\mathrm{i}}$ : 콩의 침지 전 초기 무게 $(\mathrm{g})$ 를 나타냄

\section{반응속도 상수와 활성화 에너지의 결정}

콩의 저장 온도에 의한 콩나물 수율의 변화에 있어서 등온 상 태에서의 반응 속도 식을 다음과 같이 나타낼 수 있다.

$\frac{d C}{d t}=-k(C)^{n}$

$k$ 는 반응 속도이며, $C$ 는 시간 $t$ 에 따라 변화하는 품질 인자이 며 본 연구에서는 수율을 종합적인 품질인자의 지표로 사용하 였다. 그리고 $n$ 은 반응 차수이다. 최적의 실험식을 찾기 위하여 품질인자 값을 다음 식 (4) (6)에 나타낸 0,1 차, 그리고 2차 반응 모델을 이용하여 분석하였다.

0차반응: $C_{t}=C_{0}-k t$

1차반응: $\ln \frac{C_{t}}{C_{0}}=-k t$

2차반응: $\frac{1}{C_{t}}=k t-\frac{1}{C_{0}}$

$C_{0}$ 는 시간이 $0 s$ 일 때 초기 값이며, $C_{t}$ 는 시간 $t$ 일 때의 값이며, $k$ 는 속도 상수이다. 반응 속도 $(k)$ 에 대한 온도의 영향을 분석하 고자 Arrhenius 식을 이용하였으며 반응의 온도 의존성을 나타 내는 활성화 에너지는 직선 회귀 분석에 의해 얻어지는 Arrhenius plot의 기울기(Eq. (7))로부터 계산하였다.

$k=k_{0} \exp \left(-\frac{E_{a}}{R T}\right)$

$k$ : kinetic rate constant of quality parameter

$k_{0}$ : pre-exponential constant

$E_{a}$ : activation energy $(\mathrm{kJ} / \mathrm{mol})$

$R$ : universal gas constant $(8.314 \mathrm{~J} / \mathrm{mol} \mathrm{K})$

$T$ : absolute temperature $(\mathrm{K})$

\section{영상분석}

콩의 저장 조건에 따라 콩이 콩나물로 성장 시 발아되는 정도 를 확인하기 위하여 최종 산물인 콩나물의 면적을 구하여 비교 하였다. 카메라(EOS 500D, Canon, Tokyo, Japan)를 이용하여 획득한 콩나물 사진의 RGB 이미지를 gray scale로 변환시켜 영 상을 이진화하기 위한 임계값을 설정한 후 이를 이진화하여 콩 나물의 단순화된 이미지를 얻었다. 이진화된 이미지에서 콩나물 에 해당하는 면적은 검정색으로 나타나게 하여 해당 이미지에 서 검정색을 의미하는 ' 0 ' 나타내는 픽셀을 계산하여 비교하였다. 


\section{조직감}

콩나물 자엽의 조직감은 true stress로 콩나물의 배축의 조직감 은 hardness로 비교하였다. 콩나물 자엽의 크기는 다양하기 때 문에 프로브와 접촉하는 면적을 계산하여 조직감을 확인하였다 [11]. Texture analyzer (CT3, Brookfield, Stoughton, MA, USA) 를 이용하여 compression test로 진행하였으며, 프로브는 칼날형 프로브 (TA7)를 이용하여 10 회 반복 측정을 하였다. 측정 조건 으로 변형율(deformation)은 콩나물의 자엽은 $30 \%$, 배축은 $99 \%$ 로 하였으며, 측정속도는 $0.5 \mathrm{~mm} / \mathrm{s}$, trigger load는 $7 \mathrm{~g}$ 으로 설정 하였다. 콩나물 자엽의 true stress를 구하기 위하여 $30 \%$ 변형 율 적용 시 프로브와 닿는 콩나물 자엽의 면적을 다음과 같이 구하였다.

True stress $\left(\mathrm{g} / \mathrm{mm}^{2}\right)=$ hardness $\times \sqrt{a^{2}-\frac{a^{2}}{a^{2}} y^{2}}$

$a$ 는 콩나물 자엽인 타원 모형 중 장축의 반지름 $(\mathrm{mm})$ 이며, $b$ 는 콩나물 자엽의 총 높이 $(\mathrm{mm})$ 를 기준으로 $30 \%$ 의 변형율을 적용했을 때의 콩나물 높이이다. $a$ 는 버니어 캘리퍼스(Bluebird, HongKong, China)로 측정하였으며, $b$ 를 구하기 위하여 자엽의 총 높이는 texture analyzer를 통하여 측정된 값을 이용하였다.

\section{색도}

콩나물의 색도는 색도계(CR-300, Minolta, Osaka, Japan)를 사 용하여 콩나물 자엽은 황색도 $(b)$ 를 배축은 명도 $(L)$ 를 측정하였 다. 표준 색판은 $L$ 값이 $94.50, a$ 값이 $0.3126, b$ 값이 0.3191 이 었다.

\section{유리아미노산}

콩의 저장 기간과 저장 온도에 따라 콩나물로 발아 시 콩나물 전체의 성분변화를 관찰하기 위하여 각각 발아된 시료를 $-70{ }^{\circ} \mathrm{C}$ 에서 동결한 후 진공 동결건조(TFD5503, IlShin BioBase Co., Ltd., Gyeonggido, Korea) 시켰다. 유리아미노산 조성을 알아보 기 위하여 동결 건조된 샘플을 증류수로 적정량 희석한 $5 \mathrm{~mL}$ 에 5\% TCA (Trichloroacetic acid; Sigma-Aldrich, cat. No. 522082) $5 \mathrm{~mL}$ 을 첨가한 후 원심분리 $\left(4{ }^{\circ} \mathrm{C}, 12,000 \mathrm{~g}, 15 \mathrm{~min}\right)$ 하였다. 상등 액을 회수한 다음 여과(0.2, Millipore Co., Bedford, UK)한 것 을 post column 방법으로 분석하였다. 분석에는 PF \#2622
(4.660 mm, Hitachi Co., Ltd., Tokyo, Japan) column을 사용 하였으며, 아미노산 자동분석기(L-8900, Hitachi Co.)을 사용하 였다.

\section{통계분석}

실험 결과는 SPSS 통계프로그램(version 23.0, SPSS Institute Inc., Chicago, IL, USA)을 사용하여 실험결과의 차이를 분산분 석을 통하여 $p<0.05$ 수준에서 Duncan's multiple range test로 시료 간 유의성을 검정하였다.

\section{결과 및 고찰}

\section{발아세}

콩의 저장 기간 및 저장 온도에 따른 콩나물의 발아세를 Fig. $1 \mathrm{~A}$ 에 나타내었다. 저장 6 개월 동안 $15^{\circ} \mathrm{C}$ 에서 저장된 콩의 콩 나물 발아세는 $90.08 \pm 8.00 \%$ 로 $5{ }^{\circ} \mathrm{C}$ 의 저온 하에서의 발아세와 유의미한 차이가 없는 반면 실온에서 저장된 콩의 콩나물 발아 세는 매우 낮았다(2.08\%). 12개월 저장 후에도 저장 온도 5 , $15^{\circ} \mathrm{C}$ 에서 저장된 콩을 이용한 콩나물 간의 유의미한 차이가 없 었으며 $(p<0.05)$ 실온에서 저장된 콩의 경우 발아가 일어나지 않 았다. 저장 기간 12 개월 동안 저장 시 저장 온도와 관계없이 초기와 비교하여 콩나물의 발아세가 유의미하게 감소하였다. 실 온의 조건으로 6 개월간 저장 시 콩나물의 발아세가 $3 \%$ 이하였 으며, 저장 12 개월 시 발아가 되지 않았다. 콩은 성숙되면서 생 화학적 변화가 일어나고 이화작용이 진행되면서 효소 활성의 증 가, 지방산과 막 투과성의 증가와 같은 변화에 의하여 콩의 품 질 저하가 일어난다[12]. 이화작용은 고온, 고습의 환경보다 저 온, 낮은 상대습도에서 천천히 발생되며 콩의 성숙에 따라 지 속적으로 발생되는 이화작용은 콩의 발아 능력을 감소시킨다. 그러므로 저온보다 고온에서 저장기간에 따라 이화작용이 촉진 되어 생화학적 변화 속도가 증가하여 발아세가 감소한 것으로 판단되며, 이는 $5^{\circ} \mathrm{C}$ 에서 저장한 콩의 발아세가 감소하는 연구 결과와 일치하였다[13] 콩의 저장온도가 5 와 $15^{\circ} \mathrm{C}$ 일 때 저장 기간에 따라 유의미한 차이가 없기 때문에 콩의 저장습도를 고 려한 저장실험에서는 콩이 여름철 사일로에 저장되었을 때의 온 도인 $30{ }^{\circ} \mathrm{C}$ 로 진행하였다. 콩의 저장 습도 및 저장 온도에 따
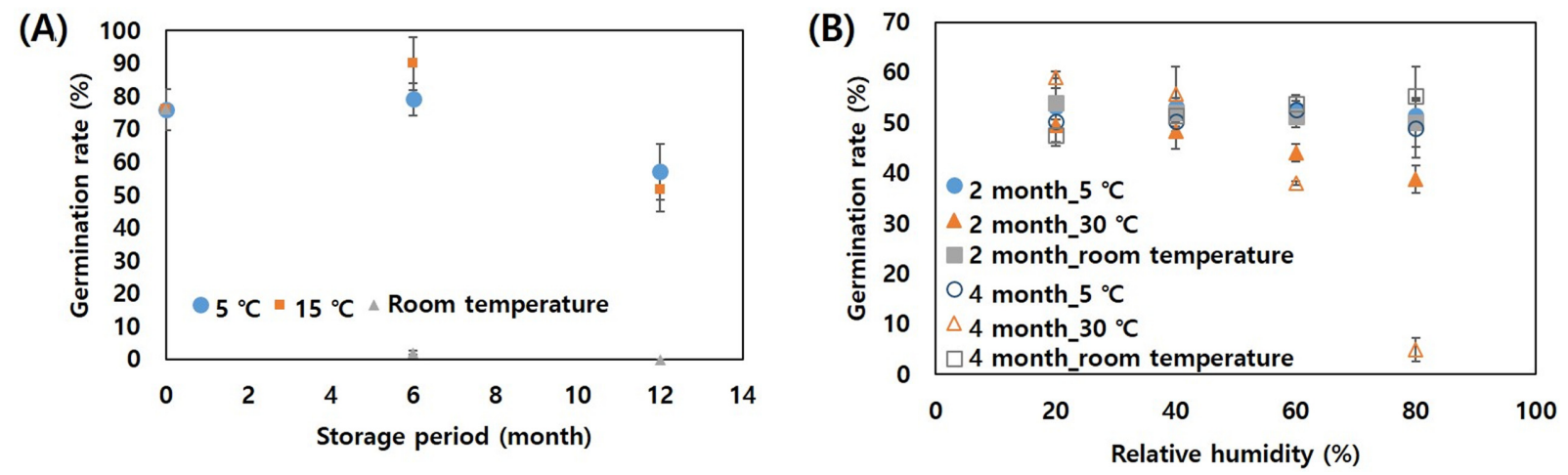

Fig. 1 Effect of storage conditions on the germination rate of soybean sprout during storage. (A) temperature controlled storage, (B) temperature and relative humidity controlled storage 

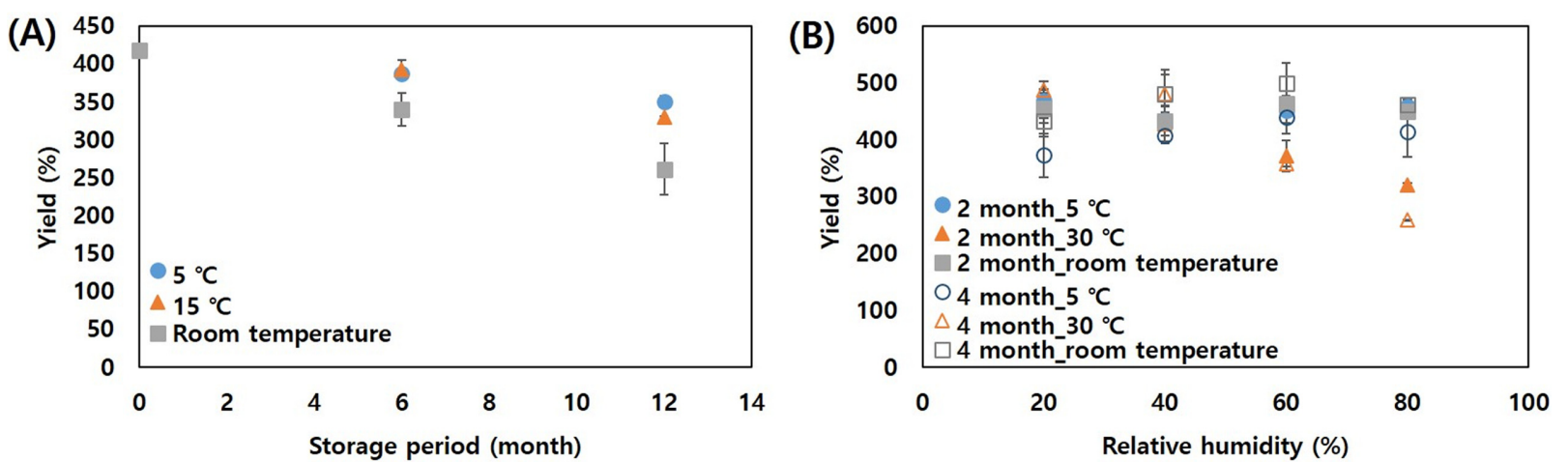

Fig. 2 Effect of storage conditions on the yield of soybean sprout during storage. (A) temperature controlled storage, (B) temperature and relative humidity controlled storage

른 콩나물의 발아세는 Fig. $1 \mathrm{~B}$ 에 나타내었다. $5^{\circ} \mathrm{C}$ 와 실온에서 저장된 콩은 저장 상대습도에 따라 유의미한 차이가 없었으나 $30{ }^{\circ} \mathrm{C}$ 에서 저장된 콩은 저장 상대습도가 $60,80 \%$ 일 때 발아세 가 감소하는 경향을 나타내었다. 콩의 수확시기가 11 월이었던 것을 고려하였을 때 실온(밀양지역의 평균 온도)에서 저장된 콩 은 $30{ }^{\circ} \mathrm{C}$ 에서 저장된 것보다 상대적으로 고온의 영향을 받지 않 아 발아세의 변화가 없었다. 콩이 4 개월 동안 $30^{\circ} \mathrm{C}$ 에서 상대 습도 $80 \%$ 조건으로 저장되었을 때 고온, 고습의 환경에서 이 화작용 촉진의 영향으로 콩나물의 발아세가 $4.93 \pm 2.34 \%$ 까지 감 소하였다. 밀양지역의 연평균 상대습도인 $67.76 \%$ 인 환경에서 저장된 콩의 발아세를 나타낸 Fig. $1 \mathrm{~A}$ 의 경우 상온에서 저장 6 개월된 콩을 이용 시 여름철 고온, 고습한 환경의 영항을 받아 발아세가 급격히 감소하였으며 이는 Fig. $1 \mathrm{~B}$ 에서 저장 4 개월 동안 저장온도 $30{ }^{\circ} \mathrm{C}$ 및 고습한 환경 $(60,80 \%)$ 에서 저장한 콩 의 발아세 감소와 일치하였다.

\section{수율}

콩의 저장 조건에 따른 콩나물의 수율은 저장 12 개월 동안 5 , $15{ }^{\circ} \mathrm{C}$ 에서 저장 시 $418.17 \sim 329.50 \%$ 이었으나 실온에서 저장 시 $261.57 \pm 34.22 \%$ 로 유의미하게 감소하였다(Fig. 2A). 높은 온도에 서 콩 저장 시 저장 기간이 길어짐에 따라 콩의 품질 저하가 발생하며, 이는 관수 후 콩이 발아되지 않고 부패하는 현상을 야기하여 발아세와 함께 수율이 감소하는 결과를 나타내었다. 콩의 저장 습도 및 저장 온도에 따른 콩나물의 수율은 Fig. 2B 에 나타내었다. 콩나물의 수율은 발아세와 동일한 경향을 나타 내어 저장 온도 $5^{\circ} \mathrm{C}$ 와 실온에서 저장된 콩을 이용한 콩나물의 수율은 $373.23 \sim 499.86 \%$ 이었으나 $30{ }^{\circ} \mathrm{C}$ 에서 저장된 것은 수율 이 $258.58 \pm 0.96 \%$ 까지 유의미하게 감소하였다. 콩을 높은 온도 및 습도에서 저장 시 $\left(30{ }^{\circ} \mathrm{C}, 88 \% \mathrm{RH}\right)$ 박테리아에 의해서 콩의 세포벽이 파괴되고, 단백질 분해 효소에 노출되어 콩이 종자발 달 동안에 합성되는 저장 단백질이 콩이 발아하는 동안 작은 펩타이드와 아미노산으로 분해되어 콩의 단백질 저하에 영향을 미친다[3]. 이와 같은 연구결과를 통하여 콩을 저온에 저장 시 실온 저장에 비하여 높은 가공적성을 나타냄을 확인할 수 있었 다. 나물 콩 품종에 따른 콩나물의 수율은 $540.00 \%$ (녹채콩) $658.32 \%$ (다원콩) 이었으며[14], 다른 나물 콩 4종(단엽, 은하, 준저리, 오리알태)으로 재배한 콩나물의 수율은 506.8 525.3\%

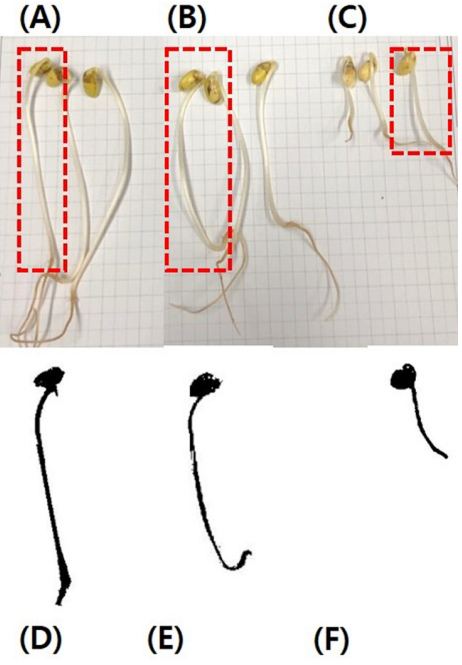

Fig. 3 RGB image of soybean sprouts stored for 6 mon at 5 (A), 15 (B), and room temperature $(\mathrm{C})$, and binary image of soybean sprouts stored for 6 months ant $5(\mathrm{D}), 15(\mathrm{E})$, and room temperature $(\mathrm{F})$

이었다[15]. 콩나물 수율의 차이는 콩의 품종 및 재배 방법에 의한 것으로 사료된다.

\section{영상분석}

저장 조건을 달리한 콩이 콩나물의 성장에 미치는 영향을 확인 하기 위하여 콩나물로의 성장 시 외형을 영상분석하여 비교하 였다(Fig. 3). Fig. 3 은 $5,15^{\circ} \mathrm{C}$, 실온에서 각각 6 개월 저장된 콩이 콩나물로 성장 시의 이미지를 나타내었다. 콩나물의 RGB 이미지를 이진화 변환하여 콩나물에 해당하는 픽셀의 수를 계 수 한 후 콩나물의 성장을 비교하였다. $5{ }^{\circ} \mathrm{C}$ 에서 12 개월 저장 된 콩이 콩나물로 발아 시 콩나물의 해당 면적은 3535 pixel 이었으며, $15^{\circ} \mathrm{C}$ 에서 저장된 콩을 이용 시 3261 pixel, 실온에 서 저장된 콩을 이용 시 2494 pixel 값을 나타내었다. 이와 같 은 영상분석의 결과는 콩이 상대적으로 저온 저장 시 수율이 높고, 고온 저장 시 수율이 낮은 Fig. 2의 수율 결과와 일치하 였다. 콩나물의 외형으로 RGB 이미지의 관심 영역을 추출 후 영상분석하는 기법은 건해삼의 수화 시 해삼의 RGB 이미지를 

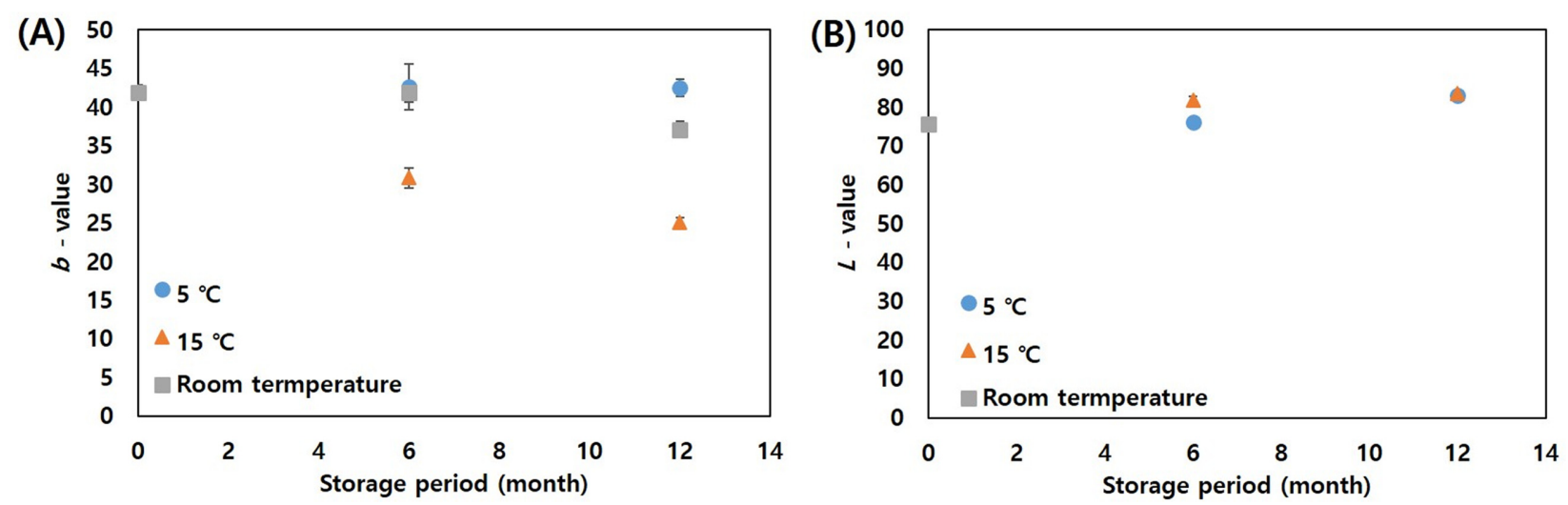

Fig. 4 The yellowness of cotyledon (A) and lightness of hypocotyl (B) of soybean sprouts according to storage period and temperature
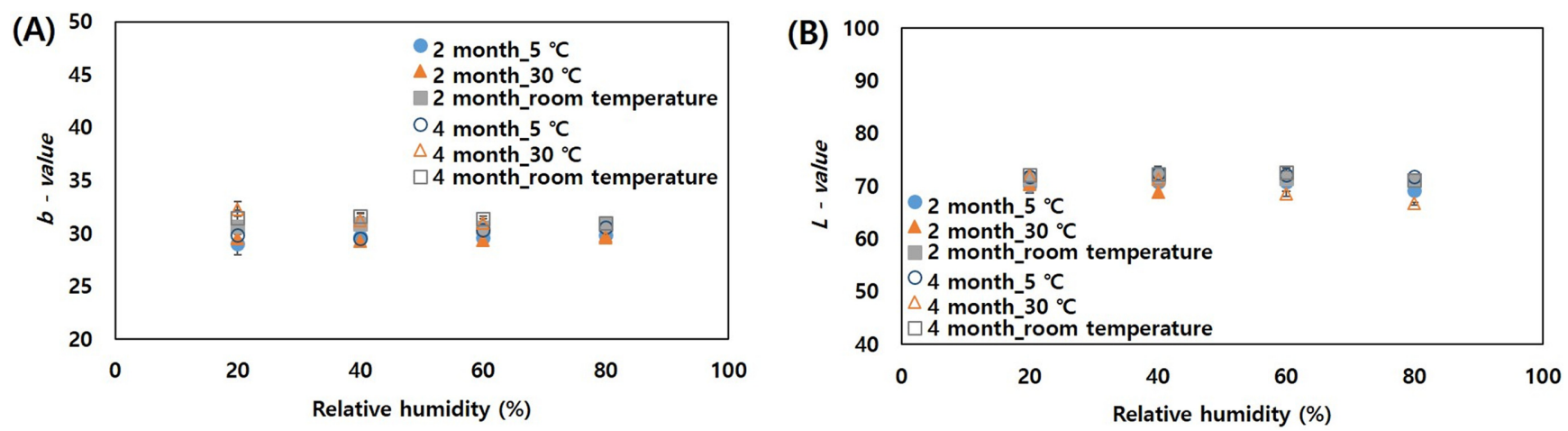

Fig. 5 The yellowness of cotyledon (A) and lightness of hypocotyl (B) of soybean sprouts according to relative humidity and temperature during storage

이용하여 형태학적 특징에 따라 분석하는 방법과 유사하다[16]

\section{색도}

콩의 저장 기간 및 저장온도에 따라 콩나물의 자엽과 배축의 색도를 측정하였다(Fig. 4). 콩나물 자엽의 황색도(Fig. 4A)는 12 개월 동안 $5^{\circ} \mathrm{C}$ 에서 저장된 콩을 사용 시 $41.93 \pm 0.93 \sim 42.66$ \pm 2.98 값을 유지하여 유의미한 차이가 없었다. $15^{\circ} \mathrm{C}$ 에서 저장 된 콩은 저장 6 개월부터 콩나물 자엽의 황색도가 감소하였으며, 실온에서 저장된 콩은 저장 12 개월부터 유의미하게 감소하였다. 저장 기간 12 개월 된 콩을 사용하였을 때 콩나물 자엽의 황색 도는 $37.13 \pm 0.67 \sim 52.66 \pm 2.98$ 값을 나타내었으며, 나물 콩 품종 에 따른 연구에서는 생콩나물 자엽의 황색도가 $34.45 \pm 0.59$ (다 원콩) 47.13 \pm 0.61 (녹채콩)이었다[14]. 이는 본 연구에서 진행한 콩나물 자엽의 황색도 값과 유사하였으며, 본 연구에서의 황색 도 값이 더 높은 것은 품종에 따른 차이인 것으로 판단된다. 또 한 콩나물은 재배 과정에서 $\beta$-carotene 함량이 증가한다고 보고 되었으며[17], 본 연구에서 $5{ }^{\circ} \mathrm{C}$ 의 저온 저장된 콩을 제외하고 $15{ }^{\circ} \mathrm{C}$ 와 실온에서 저장된 콩을 사용 시 저장 기간이 증가함에 따라 콩나물 자엽의 황색도가 감소하는 경향을 나타낸 것은 콩 의 저장 기간 동안 저장 온도에 의한 영향을 받은 것으로 생각 된다. 콩나물 배축의 명도는 Fig. $4 \mathrm{~B}$ 에 나타내었다. 저장 12 개 월 동안 $5,15^{\circ} \mathrm{C}$ 에서 저장된 콩을 사용 시 콩나물 배축의 명 도는 저장기간에 따른 큰 영향이 없었다. 콩의 저장 습도 및 저
장 온도에 따라 콩나물 자엽의 황색도와 배축의 명도는 Fig. 5 에 나타내었으며 저장 4 개월까지 콩의 저장 습도 및 저장 온도 를 달리하여 저장하였을 때 저장조건이 콩나물의 색도에 영향 을 미치지 않는 것을 확인하였다.

\section{조직감}

콩의 저장기간 및 저장온도에 따른 저장과 저장습도 및 저장온 도에 따른 콩나물의 조직감을 각각 Figs. 6, 7에 나타내었다. 콩 나물 자엽의 조직감(Fig. 6A)은 저장 6개월까지 저장 온도에 따 라 콩나물 자엽의 조직감에 유의미한 차이가 없었으며 저장 12 개월 시 저장 온도가 증가함에 따라 조직감이 감소하였다. 저 장 $5{ }^{\circ} \mathrm{C}$ 에서 저장된 콩을 사용 시 저장 기간에 따라 콩나물 자 엽의 조직감이 $58.50 \sim 62.76 \mathrm{~g} / \mathrm{mm}^{2}$ 으로 유의미한 차이가 없었 다. 콩의 저장습도 및 저장온도에 따른 콩나물 자엽의 조직감 (Fig. $7 \mathrm{~A})$ 은 콩이 상대적으로 고온 $\left(30^{\circ} \mathrm{C}\right)$ 고습 $(60,80 \%)$ 의 영 향을 받을 때 콩나물 자엽의 조직감이 감소하는 경향으로 보아 본 연구에서는 나물용 콩의 장기 보관과 콩나물의 품질을 위하 여 $5{ }^{\circ} \mathrm{C}$ 의 저온 저장 조건이 최적임을 확인하였다.

콩나물 배축의 조직감(Fig. 6B)은 저장 0 개월에서 저장 6 개 월로 저장 기간이 증가함에 따라 $5,15^{\circ} \mathrm{C}$ 에서 저장된 콩을 이 용한 콩나물의 배축 조직감이 감소하는 경향을 나타내었으며 저 장 6 개월에서 저장 12 개월까지는 $5{ }^{\circ} \mathrm{C}$ 에서 저장된 콩을 사용 시 콩나물 배축의 조직감이 $222.50 \pm 41.15,210.94 \pm 31 \mathrm{~g}$ 이었으며 

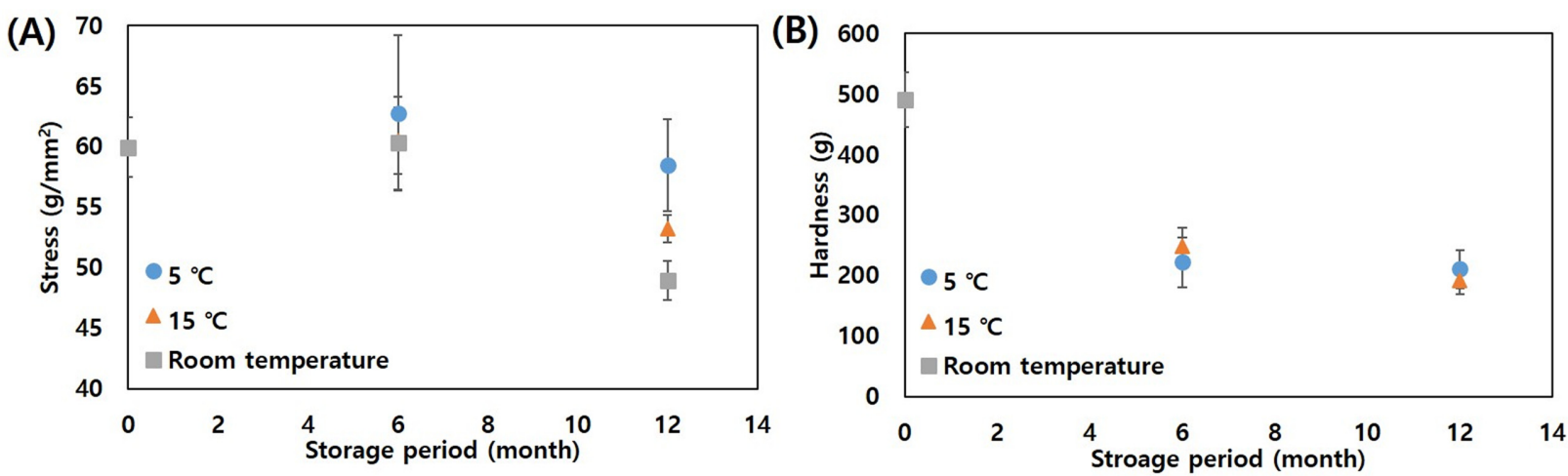

Fig. 6 True stress of cotyledon of soybean sprouts and hardness of hypocotyl of soybean sprouts according to the storage period and temperature

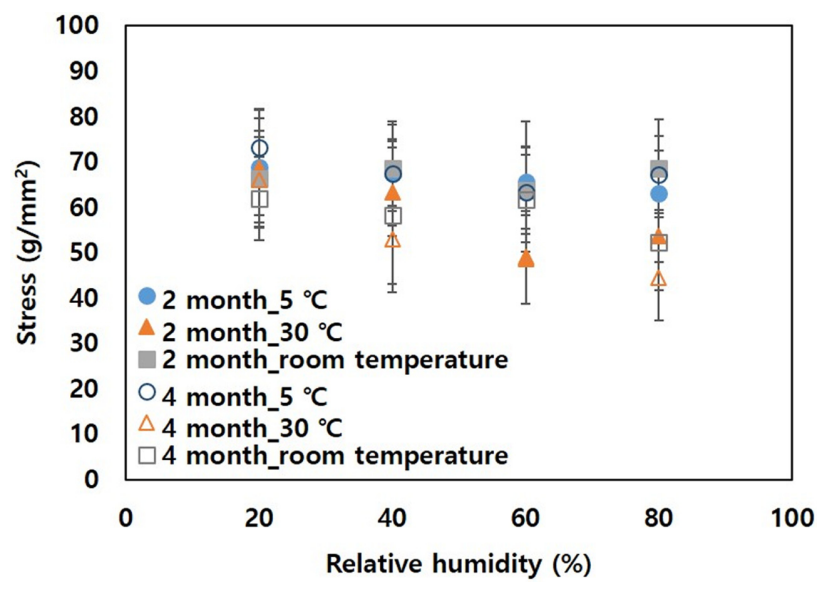

Fig. 7 True stress of cotyledon of soybean sprouts and hardness of hypocotyl of soybean sprouts according to the relative humidity and temperature during storage

$15^{\circ} \mathrm{C}$ 의 저장 조건 시에는 $248.13 \pm 31.46,192.50 \pm 23.52 \mathrm{~g}$ 로 유 의미한 차이가 없었다. 콩이 4 개월 동안 저장습도 및 저장온도 조건에 따라 저장되었을 때 콩나물 배축의 조직감은 저장조건 에 의한 영향을 받지 않아 유의미한 차이가 없었다.

\section{유리 아미노산}

콩의 저장 조건에 따른 콩나물의 13 가지의 유리 아미노산인 aspartic acid, serin, asparagine, glutamic acid, glycine, alanine, methionine, leucine, ammonia, lysine, histidine, arginine, proline의 함량을 Table 1에 나타내었다. 콩나물의 아스파라긴의 함량은 콩의 저장온도 혹은 저장기간에 따라 뚜렷한 경향을 나 타내지 않는 경우이거나 수확된 콩나물의 전체 수율에 의존적 인 것을 확인하였다. 콩나물은 실온에서 저장 기간이 증가함에 따라 발아세가 감소하였으며 콩나물의 아스파라긴 함량도 0,6 , 12 개월 저장 시 각각 $27510.87,24181.72,1698.12 \mathrm{ppm}$ 으로 감 소하였다. 이는 알코올 분해 효소의 생성을 도와주는 아스파라 긴이 뿌리에 다량 함유되어 있는 결과와 일치한다[18-20]. 또한 $5,15^{\circ} \mathrm{C}$ 에서 저장 기간이 12 개월 된 콩을 이용 하였을 시 콩 나물의 아스파라긴은 감소하였다. 콩의 저장 온도와 저장 기간 에 따라 콩나물의 발아세가 결정될 뿐만 아니라 유리아미노산
중 아스파라긴 함량에도 영향을 미치기 때문에 나물용 콩은 장 기간 보관하여 일정한 콩나물의 품질특성을 유지하기 위해서 저 온 저장이 필요할 것으로 생각되며, 이는 콩의 저장 조건에 따 른 콩나물의 품질인자를 예측할 수 있는 기초 자료로 활용될 수 있을 것으로 생각된다.

\section{수율의 온도 의존성 예측모델}

본 연구에서 측정된 저장 온도에 따른 콩나물 수율의 데이터는 3 개의 실험점 $(0,6,12$ 개월 $)$ 으로 반응모델을 만드는데 최소로 사 용할 수 있는 데이터라고 할 수 있다. 이를 바탕으로 만들어진 반응모델과 Arrhenius모델의 조변수값인 A (pre-exponential coefficient)와 $\mathrm{Ea}$ (활성화 에너지)를 이용하여 2, 4개월에서 각 온도에서의 수율을 밀양 지역의 평균상대습도와 근접한 $\mathrm{RH}$ $60 \%$ 데이터와 비교하여 예측모델을 검증하고자 하였다. 콩나물 수율에 콩의 저장온도가 미치는 영향을 0 차, 1 차, 2 차반응식(수 식4-6)에 적용한 결과 0 차반응식의 $\mathrm{R}^{2}$ 가 가장 높은 값을 나타 내었다. 이는 측정 데이터의 수가 상대적으로 충분하지 않은 상 태이며 또한 장기간의 저장에 대한 반응 모델로서 초기의 민감 한 화학반응을 나타내는 1 차와 2 차모델을 적용하기 어려운 상 태이므로 0 차모델의 적합도가 가장 높다고 판단된다.

저장온도에 따른 반응속도상수 $(k)$ 를 0 차, 1 차, 2 차반응식에 적 용 후 반응속도상수의 온도의존성을 Arrhenius 식을 이용하여 조 사하였다. 반응모델의 차수가 0 인 경우 본 연구에 사용된 모든 저장온도에서 콩나물 수율에 미치는 영향에 대한 반응식의 $\mathrm{R}^{2}$ 값이 0.93-1.00으로 가장 적합함을 보였다(Table 2). 이는 매우 오랜 기간 저장을 수행하며 수율의 변화를 관찰한 데이터를 바 탕으로 하므로 초기의 급격한 변화가 영향을 주는 1 차나 2 차모 델 보다 오랜기간 동안의 점진적인 변화를 나타내는 선형모형(0 차 반응모델)이 적합한 것으로 판단된다. 각 온도에서 얻어진 반 응속도상수를 Arrhenius모델을 통하여 활성화에너지를 계산하였 다. 저장온도에 따른 콩나물 수율 감소의 반응속도상수의 온도 의존성은 Arrhenius모델로 구현하였으며 이때의 활성화 에너지는 $29.56 \mathrm{~kJ} / \mathrm{mol}$ 이며 조변수값인 A (pre-exponential coefficient)의 값은 $1,812,935$ 이었다. 저장기간 중의 수율변화에 따른 반응속도상수 와 Arrhenius모델의 조변수값을 바탕으로 저장온도 $\left(5,15^{\circ} \mathrm{C}\right.$, 상 온)에 따른 수율을 모델값을 이용하여 예측하여 모델을 검증하 였다. 실험이 진행되지 않은 2 개월과 4 개월의 수율을 예측하여 실제 데이터(상대습도 $60 \%$ 를 기준)와 비교하여 나타내었다(Fig. 
Table 1 Change in free amino acid content ( $\mathrm{ppm})$ of soybean sprouts according to the storage period and temperature

\begin{tabular}{|c|c|c|c|c|c|c|c|c|}
\hline \multirow{2}{*}{\multicolumn{2}{|c|}{$\begin{array}{l}\text { Free amino acid } \\
\qquad(\mathrm{ppm})\end{array}$}} & \multirow{3}{*}{$\begin{array}{c}0 \text { mon } \\
1054.54 \pm \\
660.89\end{array}$} & \multicolumn{2}{|c|}{$5^{\circ} \mathrm{C}$} & \multicolumn{2}{|c|}{$15^{\circ} \mathrm{C}$} & \multicolumn{2}{|c|}{ Room temperature } \\
\hline & & & 6 mon & 12 mon & 6 mon & 12 mon & 6 mon & 12 mon \\
\hline Asp & Aspartic acid & & $\begin{array}{c}1218.59 \pm \\
394.57\end{array}$ & $\begin{array}{c}1930.94 \pm \\
300.98\end{array}$ & $\begin{array}{c}1332.97 \pm \\
325.78\end{array}$ & $\begin{array}{c}1550.99 \pm \\
245.87\end{array}$ & $\begin{array}{c}1289.39 \pm \\
247.69\end{array}$ & $\begin{array}{c}1636.29 \pm \\
201.29\end{array}$ \\
\hline Ser & Serin & $\begin{array}{l}2168.23 \pm \\
589.45\end{array}$ & $\begin{array}{c}3191.34 \pm \\
475.10\end{array}$ & $\begin{array}{l}1906.51 \pm \\
600.14\end{array}$ & $\begin{array}{l}3007.01 \pm \\
416.34\end{array}$ & $\begin{array}{c}2209.93 \pm \\
378.50\end{array}$ & $\begin{array}{c}2775.73 \pm \\
420.58\end{array}$ & $\begin{array}{c}1018.87 \pm \\
695.48\end{array}$ \\
\hline AspNH2 & Asparagine & $\begin{array}{c}27510.87 \pm \\
10458.51\end{array}$ & $\begin{array}{c}35977.54 \pm \\
10051.49\end{array}$ & $\begin{array}{c}21581.11 \pm \\
9875.41\end{array}$ & $\begin{array}{l}32119.88 \pm \\
8421.36\end{array}$ & $\begin{array}{c}26729.01 \pm \\
11898.25\end{array}$ & $\begin{array}{c}24181.72 \pm \\
9566.21\end{array}$ & $\begin{array}{c}1698.12 \pm \\
9522.26\end{array}$ \\
\hline Glu & Glutamic acid & $\begin{array}{l}251.44 \pm \\
85.12 *\end{array}$ & $\begin{array}{c}447.99 \pm \\
184.24 * *\end{array}$ & $\begin{array}{c}615.91 \pm \\
162.15 * * *\end{array}$ & $\begin{array}{c}555.93 \pm \\
108.54 * * *\end{array}$ & $\begin{array}{c}449.05 \pm \\
98.18 * * *\end{array}$ & $\begin{array}{c}847.93 \pm \\
245.89 * * *\end{array}$ & $\begin{array}{c}2669.57 \pm \\
1247.87 * * * *\end{array}$ \\
\hline Gly & Glycine & $\begin{array}{c}708.38 \pm \\
248.59\end{array}$ & $\begin{array}{l}704.70 \pm \\
211.45\end{array}$ & $\begin{array}{l}756.96 \pm \\
298.45\end{array}$ & $\begin{array}{c}677.15 \pm \\
195.45\end{array}$ & $\begin{array}{l}749.46 \pm \\
295.16\end{array}$ & $\begin{array}{c}660.43 \pm \\
189.78\end{array}$ & $\begin{array}{c}442.54 \pm \\
189.51\end{array}$ \\
\hline Ala & Alanine & $\begin{array}{c}1455.04 \pm \\
895.45\end{array}$ & $\begin{array}{c}2005.37 \pm \\
578.45\end{array}$ & $\begin{array}{c}1591.26 \pm \\
654.78\end{array}$ & $\begin{array}{c}2084.77 \pm \\
541.02\end{array}$ & $\begin{array}{c}1564.72 \pm \\
469.87\end{array}$ & $\begin{array}{c}2131.08 \pm \\
598.12\end{array}$ & $\begin{array}{c}1766.65 \pm \\
745.33\end{array}$ \\
\hline Met & Methionine & $\begin{array}{c}282.67 \pm \\
54.87\end{array}$ & $\begin{array}{c}231.11 \pm \\
49.45\end{array}$ & $\begin{array}{c}242.76 \pm \\
47.28\end{array}$ & $\begin{array}{c}222.95 \pm \\
59.15\end{array}$ & $\begin{array}{c}264.10 \pm \\
64.51\end{array}$ & $\begin{array}{c}205.11 \pm \\
37.15\end{array}$ & $\begin{array}{c}247.35 \pm \\
42.00\end{array}$ \\
\hline Leu & Leucine & $\begin{array}{c}1237.80 \pm \\
348.15\end{array}$ & $\begin{array}{c}1210.45 \pm \\
347.13\end{array}$ & $\begin{array}{c}1003.59 \pm \\
379.45\end{array}$ & $\begin{array}{c}1198.40 \pm \\
415.08\end{array}$ & $\begin{array}{c}1125.37 \pm \\
498.51\end{array}$ & $\begin{array}{c}1029.17 \pm \\
346.18\end{array}$ & $\begin{array}{c}657.68 \pm \\
249.56\end{array}$ \\
\hline NH3 & Ammonia & $\begin{array}{c}311.84 \pm \\
54.12\end{array}$ & $\begin{array}{c}333.16 \pm \\
69.78\end{array}$ & $\begin{array}{c}275.32 \pm \\
98.15\end{array}$ & $\begin{array}{c}338.51 \pm \\
84.15\end{array}$ & $\begin{array}{c}283.53 \pm \\
72.05\end{array}$ & $\begin{array}{c}260.55 \pm \\
64.15\end{array}$ & $\begin{array}{c}132.57 \pm \\
95.65^{*}\end{array}$ \\
\hline Lys & Lysine & $\begin{array}{c}1472.12 \pm \\
315.24\end{array}$ & $\begin{array}{c}1728.88 \pm \\
692.54\end{array}$ & $\begin{array}{c}1351.36 \pm \\
478.21\end{array}$ & $\begin{array}{c}1720.23 \pm \\
610.24\end{array}$ & $\begin{array}{c}1388.66 \pm \\
547.16\end{array}$ & $\begin{array}{c}1485.51 \pm \\
345.21\end{array}$ & $\begin{array}{c}823.46 \pm \\
310.24\end{array}$ \\
\hline His & Histidine & $\begin{array}{c}2267.75 \pm \\
587.14\end{array}$ & $\begin{array}{c}2689.17 \pm \\
568.12\end{array}$ & $\begin{array}{c}1813.55 \pm \\
500.15\end{array}$ & $\begin{array}{c}2470.03 \pm \\
782.54\end{array}$ & $\begin{array}{c}2201.90 \pm \\
832.41\end{array}$ & $\begin{array}{c}2039.37 \pm \\
689.12\end{array}$ & $\begin{array}{l}545.25 \pm \\
120.54^{*}\end{array}$ \\
\hline Arg & Arginine & $\begin{array}{c}4954.36 \pm \\
1025.12\end{array}$ & $\begin{array}{c}5137.93 \pm \\
1725.35\end{array}$ & $\begin{array}{c}4020.57 \pm \\
1058.01\end{array}$ & $\begin{array}{c}5478.68 \pm \\
1237.10\end{array}$ & $\begin{array}{c}4871.09 \pm \\
1689.12\end{array}$ & $\begin{array}{c}5142.14 \pm \\
1002.31\end{array}$ & $\begin{array}{c}3688.90 \pm \\
1994.65\end{array}$ \\
\hline Pro & Proline & $\begin{array}{c}858.27 \pm \\
68.54\end{array}$ & $\begin{array}{c}932.51 \pm \\
65.56\end{array}$ & $\begin{array}{c}853.64 \pm \\
70.89\end{array}$ & $\begin{array}{c}985.75 \pm \\
70.01\end{array}$ & $\begin{array}{c}901.72 \pm \\
60.30\end{array}$ & $\begin{array}{c}959.08 \pm \\
70.14\end{array}$ & $\begin{array}{c}503.19 \pm \\
80.15\end{array}$ \\
\hline
\end{tabular}

Table 2 Kinetic parameters of the zeroth, first, and second kinetic model to predict the yield of soybean sprouts at different storage temperatures

\begin{tabular}{ccc}
\hline \hline \multicolumn{4}{c}{ Zeroth order kinetic model } \\
\hline \multicolumn{4}{c}{ Storage temperature } & $\mathrm{k}\left(\%\right.$ month $\left.^{-1}\right)$ & $\mathrm{R}^{2}$ \\
\hline $5{ }^{\circ} \mathrm{C}$ & 5.501 & 0.9958 \\
$15^{\circ} \mathrm{C}$ & 6.752 & 0.9300 \\
Room temperature $\left(25^{\circ} \mathrm{C}\right)$ & 13.04 & 1.0000 \\
\hline \multicolumn{4}{c}{ First order kinetic model } \\
\hline Storage temperature & $\mathrm{k}\left(\right.$ month $\left.^{-1}\right)$ & $\mathrm{R}^{2}$ \\
\hline $5^{\circ} \mathrm{C}$ & 0.01422 & 0.9916 \\
$15^{\circ} \mathrm{C}$ & 0.01796 & 0.9151 \\
Room temperature $\left(25^{\circ} \mathrm{C}\right)$ & 0.03815 & 0.9941 \\
\hline $\mathrm{Second}$ order kinetic model \\
\hline Storage temperature & $\mathrm{k}\left(\%{ }^{-1} \mathrm{month}^{-1}\right)$ & $\mathrm{R}^{2}$ \\
\hline $5^{\circ} \mathrm{C}$ & 0.000482 & 0.9005 \\
$15^{\circ} \mathrm{C}$ & 0.000485 & 0.9005 \\
Room temperature $\left(25^{\circ} \mathrm{C}\right)$ & 0.000114 & 0.9784 \\
\hline
\end{tabular}

8). 모델을 통하여 예측한 결과 2 개월과 4 개월의 수율예측값은 모든 저장온도에서 $0,6,12$ 개월 사이에 적합하게 내삽 (interpolation) 된 것을 확인할 수 있다. 이는 본 연구에서 개발 된 모델을 사용할 경우 콩나물 콩의 수율을 12 개월의 저장 범위 내에서 다양한 영역의 저장온도에서 예측이 가능함을 제시한다.

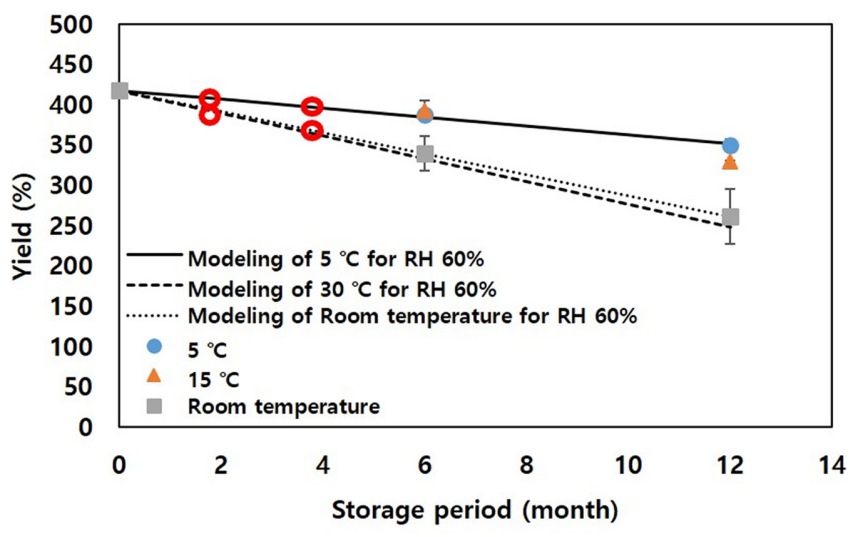

Fig. 8 Prediction of yield using the first order kinetic model and Arrhenius model at $5,30{ }^{\circ} \mathrm{C}$, and room temperature at 2 and 4 mon of storage period

\section{초 록}

나물용 콩인 해품의 저장 온도 $\left(5,15^{\circ} \mathrm{C}\right.$ 그리고 실온)및 저장 기간 $(0,6,12$ 개월 $)$, 저장 습도 $(20,40,60,80 \%)$ 에 따라 변화 하는 해품 콩나물의 가공적성을 분석하였다. 콩나물의 발아세는 콩을 실온에서 저장 시 저장 기간이 증가함에 따라 발아세가 감소하였으며 저장 12 개월이 되었을 때 $0 \%$ 이었다. $30{ }^{\circ} \mathrm{C}, 80 \%$ 
저장조건에서 4 개월 저장된 콩을 이용 시 콩나물의 발아세는 $4.94 \%$ 로 가장 낮았다. 콩나물의 수율은 콩의 저장 온도와 저장 기간이 증가함에 따라 유의미하게 감소하였으며 $(p<0.05)$, 콩의 저장 온도와 저장 습도에 따른 콩나물의 수율은 발아세의 경향 과 동일하였다. 콩나물 자엽의 황색도와 조직감, 배축의 명도와 조직감 모두 저장 기간이 증가함에 따라 감소하였다. 콩의 고 온 $\left(30{ }^{\circ} \mathrm{C}\right)$, 고습 $(80 \%)$ 의 저장조건에 의한 영향으로 콩나물 자엽 의 조직감은 $44.39 \pm 9.38 \mathrm{~g} / \mathrm{mm}^{2}$ 으로 감소하였다. 콩나물의 유리 아미노산 함량은 콩의 저장조건에 따라 뚜렷한 경향을 나타내 지 않았으며 발아세의 결과와 유사하였다. 이는 콩의 저장 조 건과 저장 기간이 콩나물의 품질인자에 영향을 미치기 때문에 저장 조건이 중요한 변수가 되는 것을 의미한다. 1차 반응속도 식과 Arrhenius식에 의해 계산된 콩나물 수율의 활성화 에너지 $(\mathrm{Ea})$ 는 $29.56 \mathrm{~kJ} / \mathrm{mol}$ 이었으며, 이를 이용하여 저장온도에 따른 수율의 예측이 가능하였다.

Keywords 발아세 - 유리 아미노산 - 저장 기간 - 저장 온도 · 콩나물

감사의 글 본 성과물은 농촌진흥청 연구사업(세부과제번호: PJ0125442019) 의 지원에 의해 이루어진 것임

\section{References}

1. Kim HS, Kim HS, Kim KH, Oh YJ, Suh SK, Park HK (2005) Water absorption and germination ratio sprout-soybean varieties affected by different planting date. Korean J Crop Sci 50: 132-135

2. Eom KY, Kim JS, Choi HS, Cha BS, Kim WJ (2006) Changes in isoflavone and some characteristics of choking of germinated soybeans during pickling in vinegar. J Korean Soc Food Sci Nutr 35(3): 359-365

3. Liu C, Wang X, Ma H, Zhang Z, Gao W, Xiao L (2008) Functional properties of protein isolates from soybeans stored under various conditions. Food chemistry 111(1): 29-37

4. Kim YH, Hwang YH, Lee HS (2003) Analysis of isoflavones for 66 varieties of sprout beans and bean sprouts. Korean J Food Sci Technol 35(4): 568-575

5. Lee SM, Hwang JY (2014) Physicochemical characteristics of soybeans grown in different origins and cultivation methods accompanying tofu properties. Korean J Food \& Nutr 27(2): 302-309

6. Jeon SH, Lee CW, Kim HY, Kim HK, Kang JH (2008) Growth of soybean affected by period and method of seed storage. Korean J Crop Sci 53(1): 21-27

7. Singh TP, Phul PS, Kaur M (1993) Effect of storage period on seed hardness and germination in soybean. Crop improvement (India) 20(2): 61-165

8. Jeon SH, Lee SH, Kim YJ, Oh SY (2010) Effects of storage temperature on physicochemical and sensory characteristics of soybean sprouts. Korean J Crop Sci 55(3): 220-225

9. Kim HS, Kim HS, Kim KH (2006) Effects of sowing date for seed quality of sprout-soybean. Korean J Crop Sci 51: 152-159

10. Song BS, Kim MJ, Kim GS (2010) Amino acid composition changes in soybean sprouts during cultivation. Korean J Food Preserv 17(5): 681687

11. Lee YJ, Jung HB, Yoon WB (2018) Investigation of the changes in texture of soybean sprout depending on the heating conditions in sousvide and conventional hot water cooking. J Appl Biol Chem 61(3): 291226

12. Shelar V, Shaikh R, Nikam A (2008) Soybean seed quality during storage: A review. Agric. Rev 29(2): 125-131

13. Suh SK, Kim KH, Kim HS, Oh YJ, Kim SD, Jang YS (1995) Effects of storage periods on germinability and characteristics of soybean-sprouts in soybean. Korea Soybean Society 12(2): 49-55

14. Shon HK, Kim YH, Lee KA (2014) Quality characteristics of bean sprouts with different Namulkong cultivars. Korean J Food Cook Sci 30(3): $340-350$

15. Choi HD, Kim SS, Hong HD, Lee JY (2000) Comparison of physicochemical and sensory characteristics of soybean sprouts from different cultivars. J Korean Soc Agric Chem Biotechnol 43(3): 207-212

16. Lee CU, Yoon WB (2017) Sea cucumber (Stichopus japonicas) grading system based on morphological features during rehydration process. J Korean Soc Food Sci Nutr 46(3): 374-380

17. Kim EJ, Lee KI, Park KY (2002) Effects of germanium treatment during cultivation of soybean sprouts. J Korean Soc Food Sci Nutr 31(4): 615620

18. Shon HK, Kim YH, Lee K (2009) Quality characteristics of Kongnamulguk with commercial soy sprouts. Korean Journal of Human Ecology 18(5): 1147-1158

19. Jeong YS, Dhakal KH, Hwang YH (2009) Change of asparagine content during soy-sprout growing. Curr Res Agric Life Sci 27: 43-52

20. Jeong YS, Dhakal KH, Hwang YH (2009) Effects of soy-sprout asparagine on hangover. Curr Res Agric Life Sci 27: 53-58 